\title{
The Development and Interpretation of African-American Female Dramas --From Harlem to Broadway
}

\author{
Yingying Wang ${ }^{1,}$, Jun Wang ${ }^{1}$ \\ ${ }^{1}$ Foreign Language Teaching Department of Jilin Animation Institute, Changchun, Jilin Province, \\ China \\ a314078961@qq.com
}

\begin{abstract}
Keywords: African-American female drama; the late twentieth century; development and interpretation.
\end{abstract}

\begin{abstract}
The late twentieth century has been the golden age of African-American female dramas. In this period, the female dramas from Harlem to Broadway have greatly contributed to the development of African-American female dramas. The author analyzes the development of African-American dramas in this period, and elaborates upon the new features of African-American female dramas from three aspects, the civil rights movement, the aesthetic form and the identity construction.
\end{abstract}

\section{Introduction}

With the end of World War II in 1945, the reform of American socio-culture has become quite evident and intense. With the commencement of the civil rights movement, the racial conflicts between Caucasians and African-Americans in the United States have become increasingly prominent. On the one hand, more and more African-Americans have been awakening. They pursue a better life and hope to gain more rights and respect. On the other hand, the racists of Caucasians still have racial discrimination. They regard African-Americans as another community. They think that African-Americans are dark and dull, just as "half devil half silly" [1]. In the struggle for social rights, the African-American writers have not stopped working. Their literature is not limited in novels. Plays and movies have also been considerably developing. The African-American playwrights have no longer been discontent with simple performances in the African-American communities. They hope to enter into Broadway, gain broader international support and draw others' attention.

During this period, a number of African-American female playwrights should not be underestimated. Among them, the most representative playwrights are Alice Childress, Lorraine Hansberry, Adrienne Kennedy and Ntozake Shange. They have injected fresh blood into African-American dramas and guided the new development and new features of African-American female plays after World War II.

\section{To Echo the Civil Rights Movement and the African-American Movement and to Highlight the Force of Solidarity}

During the middle and late twentieth century, African-American theater movement was essentially on the road of populist. Different from the previous play movements, the themes created by African-American female dramatists in this period are totally different from those of the traditional ones. They emphasize on the central consciousness of African-American female culture. They suppose that the unity and solidarity of African-Americans and they should try to obtain their independence and liberation. The African-American females have the right and obligation to participate in this fight for the civil rights movement.

Among lots of dramatic works which advocate the civil rights movement and the African-American movement, A Rainsin in the Sun is undoubtedly the most eye-catching one. This play is the masterpiece of an African-American female playwright, Lorraine Hansberry. This play is a realistic one. Its name is derived from Langston Hughes's verse, a famous African-American American writer, "What happens to a dream deferred? Does it dry up like a raisin in the sun? ... Or 
does it explode?" [2] In March 1959, A Rainsin in the Sun was firstly performed in Ethel Barrymore Theatre. The plots develop from how the Youngers, an African-American family, use the 10,000 dollars insurance benefits of the father's death. At first, the family members have different opinions on the usage of their insurance benefits. But later, they decide to support the idea of their mother, Lena idea, to buy a house in the Caucasian region. In the process of moving into Caucasians, they suffer a variety of obstructions of the Caucasian racists. Even their African-American neighbors do not support the idea of moving into the Caucasian zone. But in the end, the Youngers overcome all the difficulties and finally settle in the Caucasian area. They achieve their family dream. Once the play came out, it immediately triggered a strong response among the audience and the critics. The critics have a mixed response. Walter Kerr, the chief critic of Broadway, said: "Hansberry accurately interprets the national dynamics which can neither move forward, nor backward. $49 \%$ of the drama is anger and another $49 \%$ is controlling.... Three generations steadfastly stood side by side on the cusp." Some critics also argue that "What people cheered is not struggle carried out by people of different colors on the stage to resolve the long-standing racial problem, but some kind of old-fashioned and insipid heroic story of the laborers who pursue American dream. $\cdots$ This drama at best is a soap opera, which is well edited. The characters are still African-American faces and all of them are cliche." [3] (P332) Whatever, A Rainsin in the Sun is indeed a great success in Broadway and it won New York Drama Critics Circle Award in that year. Moreover, Hansberry became the first African-American playwright who gains this award.

After the great success of A Rainsin in the Sun, other African-American female playwrights began to try to interpret the civil rights movement from different angles with different forms. When the Rainbow is Enuf is one ingenious stroke. Ntozake Shange interpreted drama in perspective of poetry and created this unique drama with dances. The play consists of twenty poems that describe African-American females' lives. The characters in this play have no name. Only the colors of clothes can distinguish them, such as "the lady in a yellow dress lady", "the lady in a purple dress", etc. The poetry themes involve love, abandon, rape and abortion. Seven actresses in different colors separately tell their unique stories. At the end of the play, all female put hands together to highlight the power of female solidarity. This play is about how to rebuild the identity which is a taboo, the identity which is illegally deprived and the identity which is forgotten. The play traces the African-American females' inner journey, from naive to mature. It mainly describes the misunderstandings between men and women which are caused by the lack of communications, and calls on the African-American females that they should unite to create the miracle of life.

\section{To Develop the Non-mainstream Theatrical Aesthetic Form of African-American Females' Aesthetic}

The dramatists of younger generation hope to work for the African-American audience and describe American society in perspective of aesthetic. Forty years ago, James Johnson always wanted to simultaneously please Caucasians and African-Americans. However, in the middle and late twentieth century, the African-American playwrights' racial consciousness has unprecedentedly strengthened. They openly ignore the Caucasian audience's feelings and they only consider how to make their own script popular among the African audience. During this period, African-American female playwrights express their wishes for life and determination and courage of independence. They are no longer struggling to mainstream American theater form. They develop a no-compromise, free and powerful dramatic culture autonomous region, and bravely tell the voices of African-American females.

Alice Childress's drama, Trouble in Mind, is called model of African-American females' struggle for freedom. The play was firstly performed at Greenwich Mews Theatre in 1955. This drama tells the story of several African-American actors who encounter a variety of irony at work. The protagonist, Meyer, questioned the authority of the circumstances in which African-Americans surrender to Caucasians. The different opinions and conflicts with the director push the drama to its climax. Meyer tries to convene the African-American actors to change their script and struggle for their racial 
dignity. But her struggle ends in failure because the other actors give up their principles for living. Trouble in Mind immediately has become a hit in Broadway. Its copyright has been sold to a Broadway producer. However, two years later, this drama was banned because its subject is not suitable for commercial theater. The drama has been adapted into two editions with different endings. One meets the aesthetic requirements of the Caucasian audience. But Childress finally gave up this version and refused to bend to the interests of Broadway. Though this has made her miss Broadway, this drama won Best Original Play of Broadway, Obie award. And Childress has become the first African-American female who owns this honor.

\section{To Insight into African-American Females' Double Identity Consciousness and Confusions}

Different from African-Americans in the nineteenth century and early twentieth century, those in the late twentieth century have been deeply rooted in every aspect of American life. On the one hand, as American citizens, the Caucasian colonial culture has greatly influenced them; on the other hand, their traditional culture and beliefs are still working. These lead to a double identity consciousness and confusions of African-Americans. During this period, the African-American female playwrights have focused on African-American females' identity reconstruction.

Adrienne Kennedy, an African-American female playwright, is the representative of writers describing females' identity pursuit and reconstruction. Funnyhouse of a Negro is Kennedy's most famous drama. This drama explores African American's life and emotions through ultra-realism and expressionism, which contributes to Kennedy's reputation of dramatic poet. "Ego" is the main theme of Kennedy. She regards writing as "the confusion and doubt original from childhood mind and the outlet for inner emotional". By using this medium as her expression method, she aims to explain why such a thing it is". [4] Funnyhouse of a Negro tells a story of the identity cognitive crisis and confusion of a young sensitive mulatto female, Sarah. Sarah's inner heart has four important personalities - ego, Queen Victoria, Duchess of Rapp Rees and a African-American man, Luman Ba. The play starts from a scene in which Sarah in blood runs toward the stage, wearing a hangman's noose. She introduces her ethnic background to the audience and hopes she could be a Caucasian. Among Sarah's quadruple personalities, Queen Victoria and Duchess of Pulis are the symbol of the Caucasian colonists' identity. Luman Ba is the part of Africa. She believes that Luman Ba raped her mother and gave birth to her, which has brought her endless disasters. At the end of the drama, Sarah's monologue about her feelings when his mother died deepens the theme of anti-racism and identity searching in this drama.

In short, the late twentieth century is the golden age of African-American female dramas. By previous reference and imitation, it gradually moves toward to independence and maturity, forming a unique writing style and aesthetic perspective to show dramatic manifestation and boldly challenging the mainstream American theater culture, which reflects the charm and value of African-American female. As Professor WANG Jun said, "African-American female playwrights is searching and constructing African-American female cultural identity. They make great contributions to the dismantling of marginalized situation of African-American female literature, as well as the establishment of African-American female dramatic literature and criticism."[5] The consciousness of independent development of African-American female also helps to promote its social and class status, which improves the problems of American race and gender inequality, and energizes the development of American literature.

\section{Acknowledgement}

Fund project: Foundation for Social Science Researches of Education Department of Jilin Province during the Twelfth Five-year Plan. Project No.: Education Department of Jilin Province (2014) B901. 


\section{References}

[1] Lawson. Theory and Technique of Playwriting and Screenwriting [M]. China Film Press, 1979, 373.

[2] Hughes, Langston. "A Dream Defferred" Literature: Reading Fiction, Poetry, and Drama (Compact Edition)[M].Di Yanni, Robert. Ed., Boston: McGraw-Hill Companies, Inc. 2000.

[3] Scott Jr., Nathan A.. "African-American Literature". Harvard Guide to Contemporary American Writing. Daniel Hoffman. Ed., The Belknap Press of Harvard University Press, Cambridge, Massachusetts, USA, and London, England, 1979.

[4] Wilkerson, Margaret B., "Andrien Kennedy."In Trudier Harris and Thadious M. Davis, eds., Afro-American Writers after 1955: Dramatists and Prose Writers. Dictionary of Literary Biography. Vol. XXXVIII. Detroit: Cale, 1985, 162-69.

[5] WANG Jun \& MENG Qing-juan. On an Identity Criticism Study in the Dramas Written by African-American Females [J]. Journal of Jilin Institute of Chemical Technology, 2014 (2). 